\title{
Editorial
}

\section{The Critical Path}

Contemporary Islamic scholarship emerged in the mid-nineteenth century in response to the overall stagnation of Muslim society and culture. Muslim reformers advanced a simple but powerful thesis: overcoming the weaknesses and deficiencies of contemporary Muslim society requires profound social and cultural reforms, and hence a critical examination of traditional thought and institutions.

The pioneers of contemporary Islamic reform were versed in both modern Western and traditional Islamic thought. Early reformers, such as AlAfghani, Abduh, al-Kawakibi, and Iqbal critically engaged both the system of ideas inherited from the Muslim past and those received from the modern West. Their free spirit, inquisitive minds, and unyielding courage allowed them to place intellectual reform on a critical yet balanced path.

While the tradition of critical thinking they espoused continues to grow and flourish among many contemporary Muslim thinkers, the balance they maintained in criticizing the self and the other has been lost by a large segment of Muslim intellectuals. Most Muslim intellectuals are critical of either traditional Muslim scholarship or Western thought, but seldom both. This one-sidedness has turned knowledge and scholarship into a partisan tool to be used against the perceived ideological adversary.

Factors contributing to the one-sidedness of many contemporary Muslim scholars are numerous, and are often rooted in pure political or economic motives. Two factors, however, stand out as expressively theoretical and intellectual: the ahistorical view of ideas and concepts among Muslims, whereby what has been devised by early scholars is given universal and absolute validity; and the absence of an Archimedean point from which the intellectual can judge both.

For over a century now, Muslim intellectuals have been divided into two major blocs, the advocates of modernity and the defenders of Islamic tradition. The former continue to see Islam as a premodern legacy, incapable of leading Muslim society into a challenging future. Trapped in an end-of-history mindset, they have not been able to develop a critical approach to deal- 
ing with Western modernity. They have even failed to appreciate or pay attention to critical streams generated from within it.

Similarly, defenders of traditional Islam have fallen into another end-ofhistory trap that was set long ago. Dwelling on the shortcomings of the modern West, and repulsed by modern excesses, they have elected to throw the baby out with the bath water. The one-sided criticism they espouse prevents them from appreciating the organizational and scientific achievements of modern civilization.

For the better part of the twentieth century, Islamic thought strove to counteract the expansion of Western ideas and practices into Muslim society. Fearing that if Western ideas and culture were left unopposed they would displace Muslim cultures and Islamic values and norms, many Islamic thinkers elected to engage modernity in a radical and unsparing critique. Believing that affirming the self requires negating the other, these scholars developed a defensive, and occasionally apologetic, strategy that succeeded in creating enclaves of resistance from which Islamically-oriented writers were able to gather momentum and strike back against the intrusions of modernism.

While this defensive strategy was successful in protecting the Muslim world's Islamic identity, it reinforced traditionalism and stifled creativity and self-criticism, hence closing the Muslim mind and arresting the possibilities of profound renewal. By the same token, the Islam-Westernism and Islam-modernity dualities have created unnecessary psychological and social tensions, making it difficult for aspiring new generations of Muslims to embrace the positive accomplishments of the modern West, or to review critically the shortcomings of traditional ideas and practices. This tendency can be seen, for instance, in the reluctance on the part of many Muslim communities to embrace democracy and human rights, and in the enthusiasm to discover and glorify Muslim heroes. The result has been the entrenchment of authoritarian culture, the rise of hero worship, and the emergence of personality cults around political leaders and scholars.

\section{The Challenge}

Juxtaposing Islam and modernity has been counterproductive, disguising the real challenge facing both Muslim and Western societies, and obscuring the potential contribution of Islam to modern society and life. The real challenge confronting humanity today is the continuous devaluation of social conduct and the increased impoverishment of human life. While two- 
thirds of the world's population lives in absolute poverty, earning less than $\$ 2$ per day, deprived of an education and health services, affluent societies are inching toward hedonism and nihilism. The two poverties that are spreading through a globalizing culture, the material and the spiritual, are interrelated, feeding one another. Moral decline, greed, and the lack of universal responsibility are contributing to the increased income gap between the economically strong and technologically equipped and those who lack organization and technology.

The real challenge to humanity today is the hedonistic nature of the emerging global culture that glorifies pleasure and excess: excessive lifestyle, excessive sexual gratification, excessive violence, excessive wealth, excessive poverty, excessive use of natural resources, and excessive consumption in general. Consumerism is gradually becoming a world religion, and multinational corporations are doing their best to preach this new culture and religion. Individuals and groups who challenge it risk being reduced to the categories of fanaticism, extremism, and radicalism.

At the core of the excesses of globalization lies a moral and spiritual vacuum. More precisely, the excesses described above are the result of moral and spiritual deficiencies. The moral/spiritual vacuum is the outcome of two intellectual-cultural interrelated processes spanning two centuries: the decoupling of morality and spirituality; and the fragmentation of reason and the reduction of the intellectual to an expert for hire.

The decoupling of morality and spirituality is a by-product of the antagonism between the modern scholar and the priest. Because the priest was perceived as the guardian of spirituality, the intellectual sought to distance himself from the religious cult. The scholar endeavored to reconstruct a nonspiritual morality, a moral system liberated from the priest's sphere of power and influence. Hence, the rationalist Kant sought to base morality on rationality via the principle of noncontradiction (the categorical imperative), while the positivist Bentham founded morality on self-interest (utility).

With the demise of religion as a uniting force, reason was fragmented into autonomous spheres of knowledge, lacking any overarching notions and principles. Today, moral principles no longer permeate the various spheres of knowledge. For this very reason, a political realist can justify subjugating foreign nations in the name of national interests, and liberal economists can defend profit-maximizing enterprises even when they bring misery to impoverished humanity. 
Perhaps it is here, in standing against the lowly impulses that degrade life and threaten human decency and dignity, and in striving to uphold the transcendental values and ideals that have always provided humanity with meaning and purpose, that an Archimedean point can be found.

\section{The Ummatic Intellectual}

Reconciling rationality with the moral/spiritual foundation of human civilization is essential for restoring purpose and balance to global society. Here Islam makes its greatest contribution to enriching modern life, and here the Muslim intellectual can help forge an alternative to rising nihilism. The Islamically-oriented intellectual who combines critical thinking with spiritual commitment is uniquely positioned to provide the type of intellectualism the world needs today. The well-rounded intellectual who once provided purpose and direction to modern thought is gradually disappearing, and is being replaced by the one-dimensional intellectual, better known as the expert. The expert is a person who has an in-depth understanding of a single sphere of life, or even one part thereof. While expertise is important and needed, the absence of overarching values and criteria, valid across spheres of expertise, makes the process of self-correction extremely difficult.

Historically, two interrelated processes have contributed to the rise of the current state of affairs: the subordination of the will to truth to the will to power, whereby knowledge has practically become subservient to power; and the reluctance of the modern scholar and intellectual to embrace religion and spirituality.

Current cultural excesses cannot be overcome unless the moral/spiritual core of social life is reclaimed, and the will to power is subordinated to the will to truth. Such a profound cultural change cannot be achieved without the development of a civilizational project in which morality/spirituality is restored to its rightful place, the center of societal thought and action. Of course, this requires a new breed of intellectuals and a new form of intellectualism. The new intellectuals must appropriate the spiritual core of human experience, and generate new meanings and models; and they must locate themselves within the community while maintaining at all times complete autonomy from the State. This does not mean that the new intellectuals should take an anti-statist attitude, or remain aloof from the State; rather, intellectuals must be involved but free of State control. 
The new intellectualism described above resembles, albeit in a simplified way, the one adopted by the Islamic Reform Movement which can be traced back to intellectuals like Afghani and Abduh. Obscured by the global media's obsession with the violent and literalist expression of contemporary Islam, the Islamic Reform Movement has made a remarkable change in Muslim society and has developed intellectually and morally challenging positions vis-à-vis the globalizing commercial culture.

The new type of intellectual, the vanguard of contemporary Islamic intellectualism, is the ummatic intellectual. The ummatic intellectual resembles Gramsci's organic intellectual in that he/she is socially and politically tied to the community, and speaks for its struggle and challenges. Unlike the Gramscian intellectual, however, the ummatic intellectual is not merely a spokesperson of the interests of his/her community, but is actively engaged in developing and promoting a moral vision.

Although the notion of ummatic intellectual is informed by modern experience, it is not completely modern or new. It finds resemblance in countless classical Muslim scholars who effectively succeeded in limiting State power and mobilizing the historical Muslim community in support of a morally and legally autonomous civil society. The primordial ummatic intellectual is presented by a long chain of scholars, including Malik bin Anas, Abu Yusuf, Al-Juaini, Ibn Rushd, Ibn Taymiyyah, and others.

As long as the one-dimensional intellectual (being a state-person motivated by national interests, or a business-person moved by profit maximization) continues to be the most influential and effective person for deciding global trends, the dominant globalizing culture is bound to degrade humanity and demoralize society. The ummatic intellecutual (being a community-person), however, can be a source of hope for profound and serious reform in global culture and structure, and most importantly, the way we relate meaning to life.

\section{AJISS's Unwavering Commitment}

From its inception, AJISS has been committed to developing a wellrounded intellectualism and reconciling rationalism with moral commitment. For almost sixteen years, the journal has served as a forum for concerned scholars and intellectuals to explore the relevance of Islamic ideals and ideas to modern society and scholarship. Throughout the years, AJISS has encouraged self-criticism and critical thinking, opening its pages to new ideas without abandoning its faith in Universal Truth and transcendental 
good. This commitment remained constant, despite the various changes AJISS experienced, including the succession of editors. Beginning with this issue, our readers will notice that a change of guard has once again taken place. But our readers can rest assured that AJISS will remain committed to the critical path of free thinking and the promotion of excellence in Islamic scholarship.

Louay M. Safi

Editor 